\title{
PENGARUH USIA DAN PARITAS TERHADAP KEJADIAN PRE EKLAMPSIA DI RSUD SIDOARJO
}

\author{
Hinda Novianti \\ Fakultas Keperawatan dan Kebidanan \\ Universitas Nahdlatul Ulama Surabaya Jl. Smea 57 Surabaya \\ Email : Noviahinda@unusa.ac.id
}

\begin{abstract}
The Influence Of Age And Parity Of Events Pre Eklampsia In Sidoarjo General Hospital. One of the complications in pregnancy that could have an impact on maternal neonatal mortality is preeclampsia. Until now, the exact cause of preeclampsia is not known. The purpose of this study was to determine the effects of age and parity on the incidence of preeclampsia. The study design was cross-sectional analytic approach. Entire population Pregnant women and maternity hospitals in the delivery room of Sidoarjo by 450 people from January to March 2016, samples were taken using simple random sampling of 150 respondents. The independent variables were maternal age and parity, the dependent variable was the incidence of preeclampsia. The research instrument used secondary data from medical records. Then the data is processed with the process of editing, coding, processing and cleaning, were analyzed using univariate, bivariate and multivariate analysis with multiple logistic regression. Results of the research that has been conducted using the chi-square test for variables of age obtained Pearson chi-square value of 24.093 and $\mathrm{p}=$ $0.000>0.05$ of the proceeds Ho is rejected, and the variable parity performed using chisquare test of Pearson chi-square didapatkannilai 8.687 and $p=0.000>0.05$ from the results of Ho rejected. From the multiple logistic regression multivariate analysis showed calculation results Nagelkerke R 0234 square connotes age and parity variables simultaneously able to explain $23.4 \%$ of variations in the risk of preeclampsia. In conclusion there is the effect of age on preeclampsia, and there is also the effect of parity against preeclampsia.
\end{abstract}

\section{Abstrak : Pengaruh Usia dan Paritas terhadap kejadian Preeklampsia di RSUD}

Sidoarjo. Salah satu penyulit dalam kehamilan yang bisa berdampak pada kematian maternal neonatal adalah preeklampsia. Hingga saat ini penyebab pasti dari preeklampsia belum diketahui, diduga usia dan paritas merupakan beberapa factor yang dapat mempengaruhinya. Tujuan penelitian ini adalah untuk mengetahui pengaruh usia dan paritas terhadap kejadian preeklampsia. Desain penelitian ini adalah analitik dengan pendekatan cross sectional. Populasinya seluruh Ibu hamil dan bersalin di ruang bersalin RSUD Sidoarjo sebesar 450 orang mulai Januari hingga Maret 2015, sampel diambil menggunakan simple random sampling sebesar 150 responden. Variabel independen adalah usia dan paritas ibu, variabel dependen adalah kejadian preeklampsia. Instrumen penelitian menggunakan rekam medis. Kemudian data diolah dengan proses editing, coding, processing dan cleaning, dianalisis menggunakan univariat, bivariat dan multivariate dengan regresi logistic ganda. Hasil dari penelitian yang telah dilakukan menggunakan uji chi-square untuk variable usia didapatkan nilai pearson chi-square 24,093 dan nilai $p=0,000>0,05$ dari hasil tersebut Ho ditolak, dan variable paritas dilakukan menggunakan uji chi-square didapatkannilai pearson chi-square 8,687 dan nilai $p=$ $0,000>0,05$ dari hasil tersebut Ho ditolak. Dari analisis multivariat regresi logistik berganda menunjukkan hasil perhitungan Nagelkerke $R$ square 0.234 mengandung arti variabel usia dan paritas secara bersamaan mampu menjelaskan $23.4 \%$ dari variasi-variasi resiko terjadinya preeclampsia. Kesimpulannya ada pengaruh usia terhadap preeklampsia, dan ada pengaruh juga paritas terhadap preeklampsia.

Kata kunci : Usia, paritas, preeklampsia 


\section{PENDAHULUAN}

Kehamilan merupakan proses fisiologis yang terjadi dalam tubuh seorang wanita. Meskipun merupakan suatu proses fisiologis banyak sekali penyulit yang biasanya menyertai kehamilan yang dapat mengakibatkan tingginya kematian maternal, salah satu penyulit tersebut adalah preeklamsi (Prawirohardjo, 2008).

Berdasarkan SDKI (2012), rata-rata angka kematian ibu (AKI) tercatat sampai 359 per 100.000 kelahiran hidup. Hal ini mengungkapkan bahwa angka kematian ibu (AKI) mengalami peningkatan dari tahun 2007 yeng mancapai 228 per 100.000 kelahiran hidup. Mortalitas dan morbiditas pada wanita hamil dan bersalin adalah masalah besar baik di negara berkembang maupun di negara miskin, di negara berkembang lebih dari $50 \%$ kematian ibu sebenarnya dapat dicegah dengan teknologi yang ada serta biaya yang relatif rendah, sedangkan di negara miskin sekitar 25$50 \%$ kematian wanita usia subur yang disebabkan karena hal lain yang berkaitan dengan kehamilan, persalinan, dan nifas (Saifuddin, 2006). Angka kematian ibu di provinsi Jawa Timur masih tinggi. Berdasarkan laporan dari kabupaten/kota pada tahun 2013 didapat angka sebesar 107/100.000 kelahiran hidup. Penyebab kematian adalah perdarahan 23,19\%, eklamsi sebesar 39,38\%, infeksi sebesar 6,17\% dan lain-lain sebesar 31,26\%.

Angka kematian ibu lebih tinggi pada wanita yang memiliki usia-usia ekstrim yaitu $<20$ dan >35 tahun (Cunningham, 2006). Bobak (2005) mengatakan kira-kira 85\% preeklamsi terjadi pada kehamilan pertama. Paritas 2-3 merupakan paritas paling aman ditinjau dari kejadian preeklamsi dan resiko meningkat lagi pada grandemultigravida. Etiologi terjadinya preeklampsi belum bisa diketahui secara pasti sampai saat ini, tetapi ada beberapa faktor yang mempengaruhi terjadinya preeklampsi yaitu primigravida/nulliparitas, usia ibu yang ekstrim ( $<20$ th dan $>35$ th), riwayat keluarga pernah preeklampsi/eklampsi, penyakit-penyakit ginjal dan hipertensi yang sudah ada sebelum hamil, obesitas, diabetes melitus, penyakit trofoblas (70\% terjadi pada kasus molahidatidosa). Kira-kira $85 \%$ preeklamsi terjadi pada kehamilan pertama. Paritas 2-3 merupakan paritas paling aman ditinjau dari kejadian preeklamsi dan risiko meningkat lagi pada grande multigravida (Bobak, 2005). Menurut Cunningham (2006) usia aman untuk kehamilan dan persalinan adalah 23-35 tahun. Kematian maternal pada wanita hamil dan bersalin pada usia dibawah 20 tahun dan setelah usia 35 tahun meningkat, karena wanita yang memiliki usia kurang dari 20 tahun dan lebih dari 35 tahun di anggap lebih rentan terhadap terjadinya preeklamsi. Selain itu ibu hamil yang berusia $\geq 35$ tahun telah terjadi perubahan pada jaringan alat-alat kandungan dan jalan lahir tidak lentur lagi sehingga lebih berisiko untuk terjadi preeklamsi (Rochjati, 2003).

\section{METODE}

Desain penelitian yang dipakai adalah analitik, yang mana rancangan penelitian disusun untuk menganalisis, menjelaskan hubungan antara variabel usia, paritas dan kejadian preeklampsia. Dengan menggunakan metode pendekatan "cross sectional" yaitu antara variabel independen (usia dan paritas) dan variabel dependen (kejadian preeklampsia) diukur pada saat yang sama. Populasi pada penelitian ini adalah semua Ibu hamil dan bersalin di ruang bersalin RSUD Sidoarjo sebesar 450 orang. Dalam penelitian ini, sampel yang digunakan adalah sebagian Ibu hamil dan bersalin di ruang bersalin RSUD Sidoarjo sebesar 150 orang. Dengan menggunakan probability sampling (Simple Random Sampling). Variabel Independen dalam penelitian ini usia dan paritas, dan variabel dependen adalah kejadian preeklampsia. Instrument penelitian yang digunakan adalah rekam medis pasien. Pengolahan data dengan editting, scoring, coding, dan tabulating. Untuk mengetahui apakah ada pengaruh usia dan paritas terhadap kejadian preeklampsia, maka analisis data menggunakan analisis bivariat Uji Chi Kudrat $\left(X^{2}\right)$ Keeratan hubungan antara variabel bebas dengan variabel terikat ditentukan berdasarkan nilai Odds Ratio (OR), jika OR $\geq 1$ artinya factor risiko berpegaruh positif terhadap preeclampsia. Sedangkan analisis multivariate menggunakan model analisis regresi logistik yang digunakan untuk menganalisis hubungan variabel independen dengan variabel dependen kategori yang dikotomi dan menguji apakah 
probabilitas terjadinya variabel terikat dapat diprediksi dengan variabel independennya.

\section{HASIL DAN PEMBAHASAN}

\section{a. Hasil}

Tabel 1 Distribusi Frekuensi responden berdasarkan usia ibu hamil dan bersalin di RSUD Sidoarjo.

\begin{tabular}{llll}
\hline No & Usia & Frekuensi & $\begin{array}{l}\text { Persentase } \\
(\%)\end{array}$ \\
\hline 1 & Beresiko & 46 & 30,7 \\
2 & $\begin{array}{l}\text { Tidak } \\
\text { Beresiko }\end{array}$ & 104 & 69,3 \\
\hline & Jumlah & 150 & 100
\end{tabular}

Sumber : Data Sekunder, Maret 2015

Hasil penelitian pada tabel 1 menunjukkan bahwa dari 150 responden sebagian besar memiliki usia yang tidak beresiko $(69,3 \%)$

Tabel 2 Distribusi Frekuensi responden berdasarkan paritas ibu bersalin di RSUD Kabupaten Sidoarjo.

\begin{tabular}{llll}
\hline No & Paritas & Frekuensi & $\begin{array}{l}\text { Persentase } \\
(\%)\end{array}$ \\
\hline 1 & Beresiko & 82 & 54,7 \\
2 & Tidak & 68 & 45,3 \\
& Beresiko & & \\
\hline & Jumlah & 150 & 100 \\
\hline
\end{tabular}

Sumber: Data Sekunder, Maret 2015

Hasil penelitian pada tabel 2 menunjukkan bahwa dari 150 responden sebagian besar mengalami paritas beresiko $(54,7 \%)$.

Tabel 3 Distribusi Frekuensi responden berdasarkan kejadian preeklampsia pada ibu hamil dan bersalin di RSUD Sidoarjo.

\begin{tabular}{llll}
\hline No & $\begin{array}{l}\text { Kejadian } \\
\text { Preeklamps } \\
\text { ia }\end{array}$ & Frekuensi & Persentase \\
\hline 1 & Ya & 66 & 44 \\
2 & Tidak & 84 & 56 \\
\hline & Jumlah & 150 & 100 \\
\hline
\end{tabular}

Sumber : Data Sekunder, Maret 2015.
Hasil penelitian pada tabel 3 menunjukkan bahwa dari 150 responden sebagian besar tidak mengalami kejadian preeklampsia (56\%).

Tabel 4 Tabulasi Silang pengaruh usia terhadap kejadian preeklampsia

\begin{tabular}{|c|c|c|c|c|}
\hline & & Status & $\mathrm{E} \mathrm{Ib}$ & \\
\hline & & $\begin{array}{l}\text { Tidak } \\
\text { PE }\end{array}$ & $\mathrm{PE}$ & Total \\
\hline $\begin{array}{l}\text { Usia } \\
\text { ibu }\end{array}$ & $\begin{array}{l}\text { Tidak } \\
\text { Beresiko }\end{array}$ & 72 & 32 & 104 \\
\hline & Beresiko & 12 & 34 & 46 \\
\hline Total & & 84 & 66 & 150 \\
\hline
\end{tabular}

Tabel 5 Tabulasi Silang pengaruh paritas terhadap kejadian preeklampsia

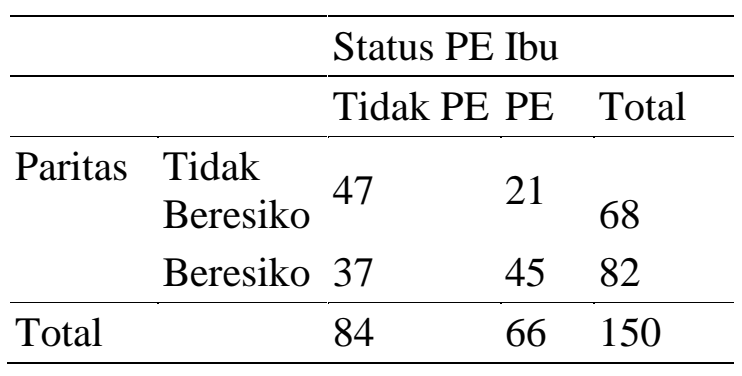

\section{Analisis Bivariat}

Tabel 6 Hasil analisis bivariat tentang pengaruh usia dan paritas terhadap kejadian preeklampsia

\begin{tabular}{llll}
\hline Variabel & Variabel & Pearso & $P$ \\
Independe & Depende & $n$ Chi & valu \\
$\mathrm{n}$ & $\mathrm{n}$ & Square & $e$ \\
\hline Usia & Kejadian & 24.093 & $<$ \\
& PE & & 0.00 \\
& & & 1 \\
Paritas & Kejadian & 8.687 & 0.00 \\
& PE & & 3 \\
\hline
\end{tabular}

Sumber : Data Sekunder, Maret 2015

Tabel 6 menunjukkan bahwa Usia Ibu dan Paritas mempunyai korelasi dengan Kejadian Preeklampsia di RSUD Kabupaten Sidoarjo. Berdasarkan tabel 5.6 dapat disimpulkan bahwa Usia memiliki 
pengaruh positif yang kuat terhadap kejadian preeklampsia dengan nilai $\mathrm{p}=$ $0.000 ; p<0.05$. Variabel Paritas memiliki pengaruh positif yang kuatterhadap kejadian preeklampsia nilai $\mathrm{p}=0.003 ; \mathrm{p}<$ 0.05 .

\section{Analisis Multivariat}

Tabel 7 Hasil analisis multivariat regresi logistik berganda pengaruhusia dan paritas terhadap kejadian preeklampsia.

\begin{tabular}{|c|c|c|c|}
\hline Variabel & Interval & kinan & $5 \%$ \\
\hline & $\begin{array}{l}\text { Exp } \\
\text { (B/OR) }\end{array}$ & B & $\begin{array}{l}\text { Nila } \\
\text { i p }\end{array}$ \\
\hline Konstanta & 0.304 & $\begin{array}{l}- \\
1.191\end{array}$ & $\begin{array}{l}0.0 \\
00\end{array}$ \\
\hline Usia & 5.588 & 1.721 & $\begin{array}{l}0.0 \\
00\end{array}$ \\
\hline Paritas & 2.117 & 0.750 & $\begin{array}{l}0.0 \\
43\end{array}$ \\
\hline $\begin{array}{l}\mathrm{N} \\
\text { Observasi } \\
\text { Nagelkerke } \\
R \text { Square }\end{array}$ & $\begin{array}{l}150 \\
0.234\end{array}$ & & \\
\hline
\end{tabular}

Interpretasi hasil analisis sebagai berikut: usia yang beresiko akan meningkatkan resiko kejadian preeklampsia sebesar 5.588 kali $(\mathrm{OR}=$ 5.588, CI 95\%; p < 0.001), sedangkan paritas yang beresiko akan meningkatkan resiko kejadian preeklampsia sebesar 2.117 kali OR $=2.117$, CI 95\%; $\mathrm{p}=0.043$

Dari analisis multivariat regresi logistik berganda menunjukkan hasil perhitungan Nagelkerke $R$ square 0.234 mengandung arti variabel usia dan paritas secara bersamaan mampu menjelaskan $23.4 \%$ dari variasi-variasi resiko terjadinya preeklampsia, sedangkan sisanya oleh variabel lain yang tidak diteliti.

Hasil dari penelitian yang telah dilakukan menggunakan uji chi-square untuk variable usia didapatkan nilai pearson chi-square 24,093 dan nilai $p=$ 0,000>0,05 dari hasil tersebut Ho ditolak, dan variable paritas dilakukan menggunakan uji chi-square didapatkannilai pearson chi-square 8,687 dan nilai $p=0,000>0,05$ dari hasil tersebut Ho ditolak. Dari analisis multivariat regresi logistik berganda menunjukkan hasil perhitungan Nagelkerke $R$ square 0.234 mengandung arti variabel usia dan paritas secara bersamaan mampu menjelaskan $23.4 \%$ dari variasi-variasi resiko terjadinya preeklampsia.

\section{b. Pembahasan}

1. Pengaruh Usia terhadap Preeklampsia Berdasarkan hasil penelitian pada tabel 6 pengaruh usia dan paritas terhadap kejadian preeklampsia di RSUD Sidoarjo bulan April 2015 didapatkan hasil bahwa usia mempunyai pengaruh yang signifikan terhadap kejadian preeklampsia nilai $\mathrm{p}<$ 0.05 .

Berdasarkan Tabel 4 menunjukkan bahwa prosentase data usia ibu dengan kejadian preeklampsia pada umur ibu beresiko yaitu $<20$ tahun dan $>35$ tahun lebih banyak yaitu 34 orang $(73,9 \%)$ dibandingkan dengan usia tidak beresiko (20 - 35 tahun) yaitu sebanyak 12 orang $(26,1 \%)$. Hasil dari penelitian yang telah dilakukan menggunakan uji chi-square didapatkan nilai pearson chi-square 24,093 dan nilai $p=0,000>0,05$ dari hasil tersebut Ho ditolak dan Ha diterima maka dapat disimpulkan bahwa ada pengaruh yang signifikan antara faktor usia denganresiko terjadinya preeklampsia, hal tersebut dimungkinkan sebagian besarumur ibu adalah usia reproduksi (20-35 tahun). Ibu berumur antara 20-29 merupakan umur terendah penyumbang kematian ibu dan bayi, sementara ibu yang lebih muda atau lebih tua mempunyai resiko yang besar, kehamilan ibu dengan umur 16 tahun terjadi peningkatan resiko terjadi preeklampsi, umur $>35$ berada pada resiko tinggi dan $>40$ mempunyai resiko sangat tinggi.

Berdasarkan $\mathrm{OR}=5.588$ dan $\mathrm{CI}$ $95 \%$ artinya ibu hamil usia risiko tinggi 
mempunyai peluang 5.588 kali mengalami kejadian preeklampsia dibandingkan dengan ibu hamil usia reproduksi. Nilai OR $>1$, maka artinya usia ibu merupakan faktor resiko terjadinya preeklampsia, hal tersebut sama dengan penelitian yang dilakukan oleh Afni Sucita Resmi (2013) dimana nilai $p=0,015$ yang berarti ada hubungan antara umur dengan preeklampsia Penelitian Apriliani (2008) yang menyatakan ada hubungan yang signifikan antara umur dengan kejadian preeklampsia $(\mathrm{p}=0,02)$.

Penelitian ini menemukan proporsi ibu yang berusia dalam kategori usia risiko tinggi $(<20$ tahun dan $>35$ tahun) dan menderita preeklampsia 5.588 kali lebih banyak daripada yang tidak menderita preeklampsia, dibandingkan dengan ibu yang berusia dalam ketegori usia risiko rendah (20 - 35 tahun). Berdasarkan analisis statistik menggunakan uji chi square, ditemukan adanya hubungan yang signifikan antara usia ibu dengan kejadian preeklampsia. Maknanya, ibu yang berusia $<20$ tahun dan > 35 tahun mempunyai kecenderungan untuk mengalami preeklampsia dibandingkan dengan ibu yang berusia $20-35$ tahun. Penelitian sebelumnya juga mendapatkan bahwa terdapat hubungan $(p=0,00)$ antara ibu yang memiliki usia pada kategori risiko tinggi dengan kejadian preeklampsia dan nilai OR sebesar 3,73. Pada penelitian lain juga didapatkan bahwa ibu yang berusia dalam kategori usia risiko tinggi memiliki risiko 5,089 kali mengalami preeklampsia dibandingkan dengan ibu yang berusia dalam kategori usia risiko rendah.

Preeklamsia adalah kumpulan gejala yang timbul pada ibu hamil, bersalin dan dalam masa nifas. Gejala klinis berupa hipertensi dan proteinuria yang timbul karena kehamilan akibat vasospasme dan aktivasi endotel saat usia kehamilan di atas 20 minggu (Cunningham, 2006). Preeklampsia merupakan salah satu penyulit dalam kehamilan yang menyebabkan sakit berat, kecacatan jangka panjang, serta kematian pada ibu dan janin. Berdasarkan penelitian yang telah dilakukan ditemukan dari 94 ibu bersalin didapatkan 26 orang $(27,7 \%)$ ibu yang mengalami kejadian preeklamsia. Menurut peneliti angka kejadian preeklampsia ini cukup tinggi. Kejadian ini bisa saja disebabkan oleh banyak faktor diantaranya usia dan paritas ibu.

Usia reproduktif dari seorang wanita adalah $20-35$ tahun. Usia reproduktif ini merupakan periode yang paling aman untuk hamil dan melahirkan karena pada usia tersebut risiko terjadinya komplikasi selama kehamilan lebih rendah. Usia di bawah 20 tahun dan di atas 35 tahun disebut juga sebagai usia risiko tinggi untuk mengalami komplikasi selama kehamilan. Pada usia< 20 tahun, ukuran uterus belum mencapai ukuran yang normal untuk kehamilan, sehingga kemungkinan terjadinya gangguan dalam kehamilan seperti preeklampsia menjadi lebih besar. Pada usia > 35 tahun terjadi proses degeneratif yang mengakibatkan perubahan sruktural dan fungsional yang terjadi pada pembuluh darah perifer yang bertanggung jawab terhadap perubahan tekanan darah, sehingga lebih rentan mengalami preeclampsia.

Penelitian yang dilakukan oleh Rozikhan (2007) didapatkan hubungan antara usia $<20$ tahun dengan kejadian preeklampsia, namun tidak terdapat hubungan antara usia > 35 tahun dengan kejadian preeklampsia.

\section{Pengaruh Paritas terhadap Preeklampsia}

Berdasarkan hasil penelitian pada tabel 5.6 pengaruhusia dan paritas terhadap kejadian preeklampsia di RSUD Sidoarjo bulan April 2015 didapatkan hasil bahwa usia mempunyai pengaruh yang signifikan terhadap kejadian preeklampsia nilai $\mathrm{p}<$ 0.05 .

Berdasarkan Tabel 5 menunjukkan bahwa persentase data paritas ibu dengan kejadian preeklampsia pada paritas ibu beresiko yaitu primigravida dan 
grandemulti lebih banyak yaitu 45 orang $(54,9 \%)$ dibandingkan dengan paritas tidak beresiko (multigravida) yaitu sebanyak 37 orang $(45,1 \%)$. Hasil dari penelitian yang telah dilakukan menggunakan uji chisquare didapatkan nilai pearson chi-square 8,687 dan nilai $p=0,000>0,05$ dari hasil tersebut Ho ditolak dan Ha diterima maka dapat disimpulkan bahwa ada pengaruhyang signifikan antara faktor paritas dengan resiko terjadinya preeklampsia, hasil tersebut dimungkinkan masih banyak paritas responden yang memiliki paritas ideal (multigravida) hal tersebut membenarkan hasil penelitian ini.

Berdasarkan analisis nilai $\mathrm{OR}=$ 2.117 dan CI 95\%, artinya ibu hamil paritas primigravida dan grandemultigravida mempunyai peluang 2.117 kali mengalami kejadian preeklampsia dibandingkan dengan ibu hamil multigravida. Nilai OR $>1$, maka artinya paritas ibu merupakan faktor resiko terjadinya preeklampsia. Paritas yang ideal adalah $2-3$, ibu yang mempunyai anak $>5$ memiliki kecenderungan untuk mengalami masalah dalam kehamilannya (Siswosudarmo, 2008). Pada primigravida memiliki kecenderungan terjadi preeklampsia dua kali lipat lebih besar (JNPK-KR, 2009).

Preeklampsia lebih sering terjadi pada kehamilan pertama dibandingkan dengan kehamilan berikutnya. Hal ini disebabkan karena pada kehamilan pertama pembentukan blocking antibodies terhadap antigen plasenta tidak sempurna, yang semakin sempurna pada kehamilan berikutnya. Secara teori, primigravida lebih berisiko untuk mengalami preeklampsia daripada multigravida karena preeklampsia biasanya timbul pada wanita yang pertama kali terpapar vilus korion. Hal ini terjadi karena pada wanita tersebut mekanisme imunologik pembentukan blocking antibody yang dilakukan oleh HLA-G (human leukocyte antigen $G$ ) terhadap antigen plasenta belum terbentuk secara sempurna, sehingga proses implantasi trofoblas ke jaringan desidual ibu menjadi terganggu. Primigravida juga rentan mengalami stres dalam menghadapi persalinan yang akan menstimulasi tubuh untuk mengeluarkan kortisol. Efek kortisol adalah meningkatkan respon simpatis, sehingga curah jantung dan tekanan darah juga akan meningkat (Yie et all, 2008).

Preeklampsia adalah penyakit dengan gejala klinis berupa hipertensi dan proteinuria yang timbul karena kehamilan akibat vasospasme dan aktivasi endotel saat usia kehamilan di atas 20 minggu. 1,2 Preeklampsia merupakan salah satu penyulit dalam kehamilan yang menyebabkan sakit berat, kecacatan jangka panjang, serta kematian pada ibu, janin dan neonatus.

\section{SIMPULAN}

Berdasarkan dari hasil penelitian dapat disimpulkan bahwa Ada Pengaruh Usia ibu hamil dan bersalin terhadap Kejadian Preeklampsia di RSUD Kabupaten Sidoarjo. Ada Pengaruh Paritas terhadap Kejadian Preeklampsia di RSUD Kabupaten Sidoarjo.

\section{SARAN}

Bagi Tempat Penelitian

Hasil penelitian ini diharapkan mampu menambah data pada RSUD Kabupaten Sidoarjo, sehingga bisa melakukan evaluasi dalam pelayanan kebidanan khususnya untuk kejadian preeklampsia di RSUD Kabupaten Sidoarjo.

\section{Bagi Institusi}

Penelitian ini diharapkan dapat menambah referensi dalam perpustakaan Universitas Nahdlatul Ulama Surabaya sehingga bisa dijadikan bahan bacaan serta gambaran bagi peneliti selanjutnya. Hasil penelitian ini bisa dijadikan referensi data untuk pendalaman mata kuliah yang berhubungan dengan Kejadian Preeklampsia.

\section{Bagi Peneliti Selanjutnya}

Penelitian ini diharapkan dapat menjadi bahan acuan penelitian selanjutnya dengan mengambil beberapa faktor lain yang 
menyebabkan dan mempengaruhi terjadinya preeklampsia, sehingga dapat memberikan sumbangan bagi ilmu pengetahuan khususnya di bidang kebidanan.

\section{DAFTAR PUSTAKA}

Bobak. 2005. Buku Ajar Keperawatan Maternitas (edisi 4). Jakarta: EGC.

Cunningham, F. G,dkk. 2006. Obstetri William Volume 1-2 edisi 21. Jakarta: EGC.

Dinas Kesehatan Kabupaten Sidoarjo. 2013. Profil Kesehatan Kabupaten Sidoarjo 2013. Sidoarjo: Dinas Kesehatan Kabupaten Sidoarjo.

JNPK-KR. 2009. Asuhan Persalinan Normal dan Inisisasi Menyusui Dini. Jakarta : JNPK-KR

Prawirohardjo, S. 2008. Ilmu Kebidanan. Jakarta: PT Bina Pustaka Sarwono Prawirohardjo.

Rochjati, P. 2003. Skrining Antenatal pada Ibu Hamil. Surabaya: Pusat safemotherhood.

Rozikhan. 2007. Faktor-Faktor Risiko Terjadinya Preeklamsia Berat di Rumah Sakit DR. H. Soewondo Kendal. Semarang, Universitas Diponegoro

Saifuddin, Abdul Bari. Siswosudarmo, R. 2006. Obstetri Fisiologi. Yogyakarta: Pustaka Cendekia. 